\title{
Disappearance of the Cuticle and Wax in Outermost Layer of Callus Cultures and Decrease of Protective Ability against Microorganisms
}

\author{
Takeo UchIYAma and Nagahiro Ogasawara \\ Department of Agricultural Chemistry, Faculty of Agriculture, Nigata University \\ Received January 17, 1977
}

\begin{abstract}
In electron microscopic observation, neither wax nor cuticle was observed on the outermost layers of callus tissues. Chemical estimation of wax in the callus surface was attempted by thin-layer chromatography of solvent extracts of callus tissues in comparison with those of barley and rice leaves. Hydrocarbons and free alcohols were detected in lyophilized callus tissues, but no wax esters or ketones were detected. Germination test indicated that germination of spores of Aspergillus oryzae was less favored on hydrophobic membranes than that of spores of Alternaria sp. and Botrytis cinerea.

From these results, we inferred that the lack of cuticle and wax in the outermost layer of callus tissues facilitated spore germination and penetration, and $A$. oryzae, a saprophytic fungus, could also readily penetrate into callus tissues.
\end{abstract}

Investigating ${ }^{1)}$ responses of callus cultures of rice to the inoculation of condia of Pyricularia oryzae and other fungi, we found that spores of Aspergillus oryzae, a saprophytic fungus, could easily invade callus tissues of rice and that, in the case of Cochliobolus miyabeanus, invasion occurred without observable formation of appressoria, whereas $P$. oryzae formed appressoria and infection pegs on rice callus. From this observation, we inferred that many fungi could penetrate callus tissues more easily than normal leaves because of the deficiency of cuticle and wax layers which are present on normal leaf surface and protect the plant from the invasion of pathogens.

In this paper we present evidence that callus tissues are devoid of the cuticle and wax layer, and discuss the reason for the loss of protective ability of callus tissues against microorganisms.

\section{MATERIALS AND METHODS}

Establishment and maintenance of tissue cultures

Rice $^{1)}$ (Oryza sativa L., Te-Tep) and barley ${ }^{2)}$ (Hordeum vulgare L., Chusei-goal) callus tissues were induced from seedlings on Murashige-Skoog's medium containing $1 \times 10^{-4} \mathrm{M}$ of 2.4-dichlorophenoxyacetic acid (2.4-D) for rice callus tissues and $2.3 \times 10^{-4} \mathrm{M}$ for barley callus tissues. Soybean (Glycin max L., T-201) callus tissues kindly supplied by Dr. Niizeki of the National Institute of Agricultural Sciences, Hiratsuka, were induced from cotyledon on modified MurashigeSkoog's medium (yeast extract powder was not added) containing $1 \times 10^{-4} \mathrm{M}$ of $2.4-\mathrm{D}$. All of these callus cultures were incubated at $30^{\circ} \mathrm{C}$ in the dark.

\section{Preparation for electron microscopy}

For electron microscopic observation, callus tissues were successively fixed in gultaraldehyde $(2 \%)$ and in osmium tetraoxide $(1.3 \%)$, both bufferized at $\mathrm{pH} 7.4$ with $0.1 \mathrm{M} \mathrm{Na} 2 \mathrm{HPO}_{4}-\mathrm{NaH}_{2} \mathrm{PO}_{4}$. After fixation, callus tissues were dehydrated in a graded ethanol series, infiltrated with and embedded in epon 812 . Thin serial sections were stained with uranyl acetate, followed by post-staining with lead acetate. Sections were examined in JEM-100B electron microscopy. For the purposes of observing callus surface, the lyophilized callus tissues were coated with carbon and gold and viewed with a JEM-2 or JEM-100B equipped with a scanning attachment.

\section{Extraction and detection of leaf wax}

Lyophilized rice callus tissues $(5 \mathrm{~g})$ were extracted with diethyl ether by immersion for $30 \mathrm{sec}$, and raw callus tissues ( $13 \mathrm{~g}$ ) were also extracted twice with the same solvent by dipping each for $20 \mathrm{sec}$, followed by filtration. The filtrates were dehydrated with sodium sulfate anhydrous, and the solvents were evaporated in vacuo. Leaf wax of rice (stage of nursery bed) and barley leaves ${ }^{3)}$ (first leaves) were extracted by immersion in diethyl ether for $15 \mathrm{sec}$. These rapid ex- 
traction methods were chosen to avoid contamination of intercellular materials. Solvent extracts of callus and leaves were examined by TLC (Kieselgel G) with the following solvent systems; benzene: $n$-hexane $(1: 1)$, carbon tetrachloride and benzene; chloroform $(7: 3)$.

\section{Germination test}

Germination of fungal spores was carried out on the wax laid on a cover glass, slide glass or $1 \%$ agar plate. To prepare wax-coated cover glass, $10 \mathrm{mg}$ wax (octa- cosan, or eicosylpalmitate) was dissolved in chloroform $(3 \mathrm{ml})$, and a cover glass dipped for a few sec. in the solution, followed by raising and drying.

The fungi used for the study of germination were Alternaria sp., Botrytis cinerea and Aspergillus oryzae. Alternaria sp. and B. cinerea were grown on potato- $2 \%$ sucrose agar, and A. oryzae was cultured on CzapekDox agar at $28^{\circ} \mathrm{C}$. To obtain spores, 7 -day-old cultures in agar media were flooded with sterile distilled water,
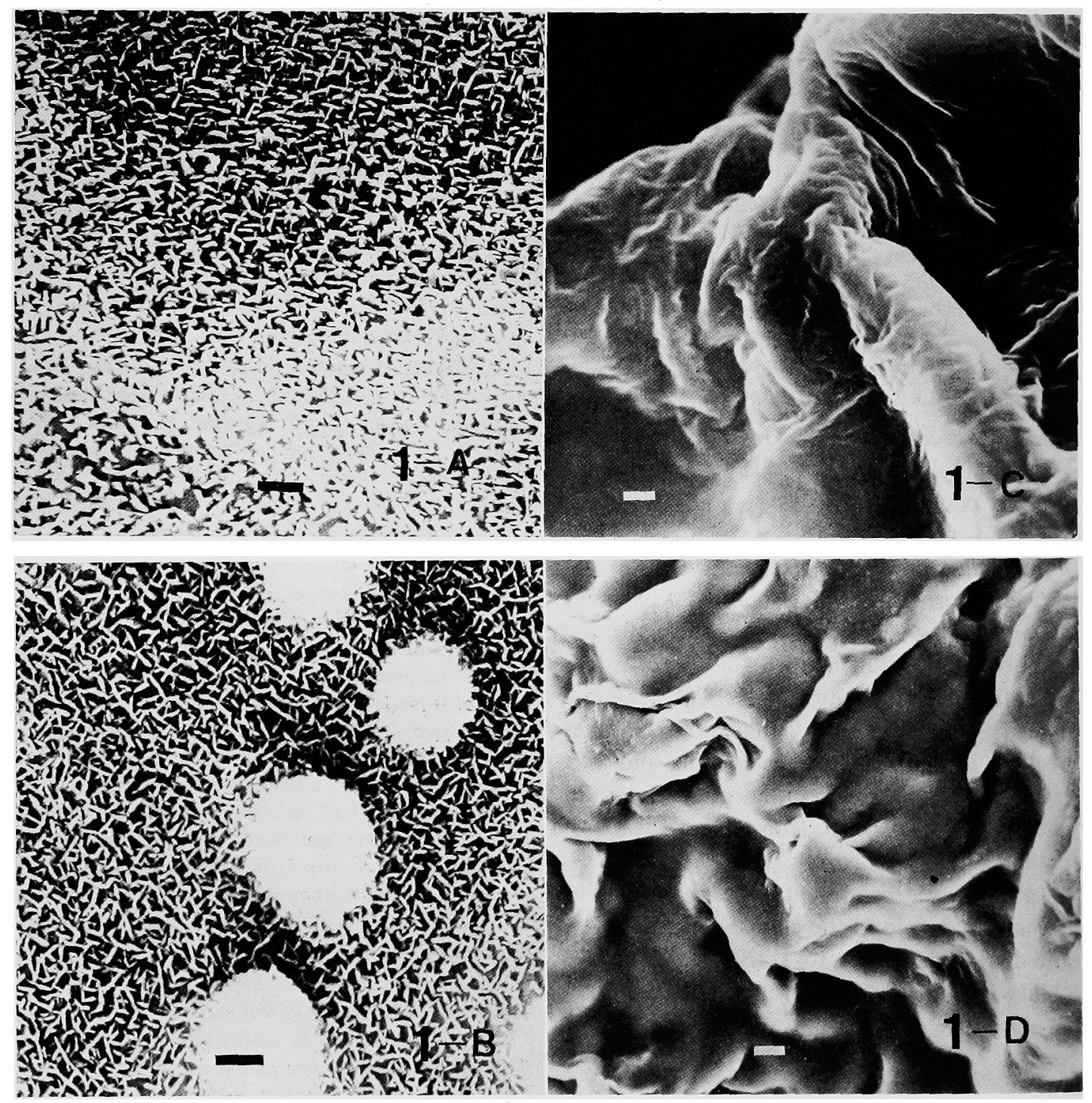

Fig. 1. Scanning Electron Micrographs of Callus and Plant Leaf Surface.

A. Leaf surface of barley having crystalline surface wax deposits.

B. Leaf surface of rice having crystalline surface wax deposits.

C. Callus surface of barley showing a smooth surface without crystalline surface wax deposits.

D. Callus surface of rice showing the same structure as in that of barley.

The scale lines represent $1 \mu \mathrm{m}$. 
and the surfaces of the cultures were scraped with glass rods. Each spore suspension was then filtered through cheesecloth, and the spores were diluted to about 100 spores/low power field $(\times 150)$ of the microscope. One drop of the spore suspension was placed on the slide glass, wax-coated cover glass or agar plate. These were placed in a moist chamber and incubated in the dark at $28^{\circ} \mathrm{C}$. After 7 to $8 \mathrm{hr}$, the percentage values of spore germination were determined.

\section{RESULTS}

Electron microscopic abservation of outermost layer of callus tissues

Figure 1 shows the surfaces of callus tissues and leaves. Callus surfaces (Fig. 1, C and D) were shrunk by lyophilization, but the wax structure which was present on rice and barley leaf surfaces (Fig. 1, A and B) was not observed. Soybean callus tissues had the similar structure to rice and barley ones. . In order to detect a cuticle layer, ultra thin sections of callus tissues were observed with an electron microscope. The results are shown in Fig. 2, A and $B$. The outermost layers of rice callus tissues were homogeneous, and the cuticle ${ }^{43}$ structure which were present on barley leaves (Fig. 2, B) was not observed. Barley callus showed a similar structure to that of rice callus tissues.

\section{Detection of wax components in solvent extracts of callus tissues}

The most common components of wax ${ }^{5}$ are hydrocarbons, wax esters, free fatty alcohols and ketones. If the wax which is embedded in cuticle exists in the outermost layer of callus tissues, the wax components will be extracted with organic solvents and be able to be detected. Chemical estimation of the wax fraction in the outermost layer of callus tissues was attempted with TLC with the solvent extracts of callus tissues, compared with those of barley and rice leaves.

Figure 3 shows the chromatograms using the solvent system of benzene: $n$-hexane $(1: 1)$. Rice leaf wax possessed the same components as those of barley leaf wax. ${ }^{3)}$ Hydrocarbons and free fatty alcohols were detected in

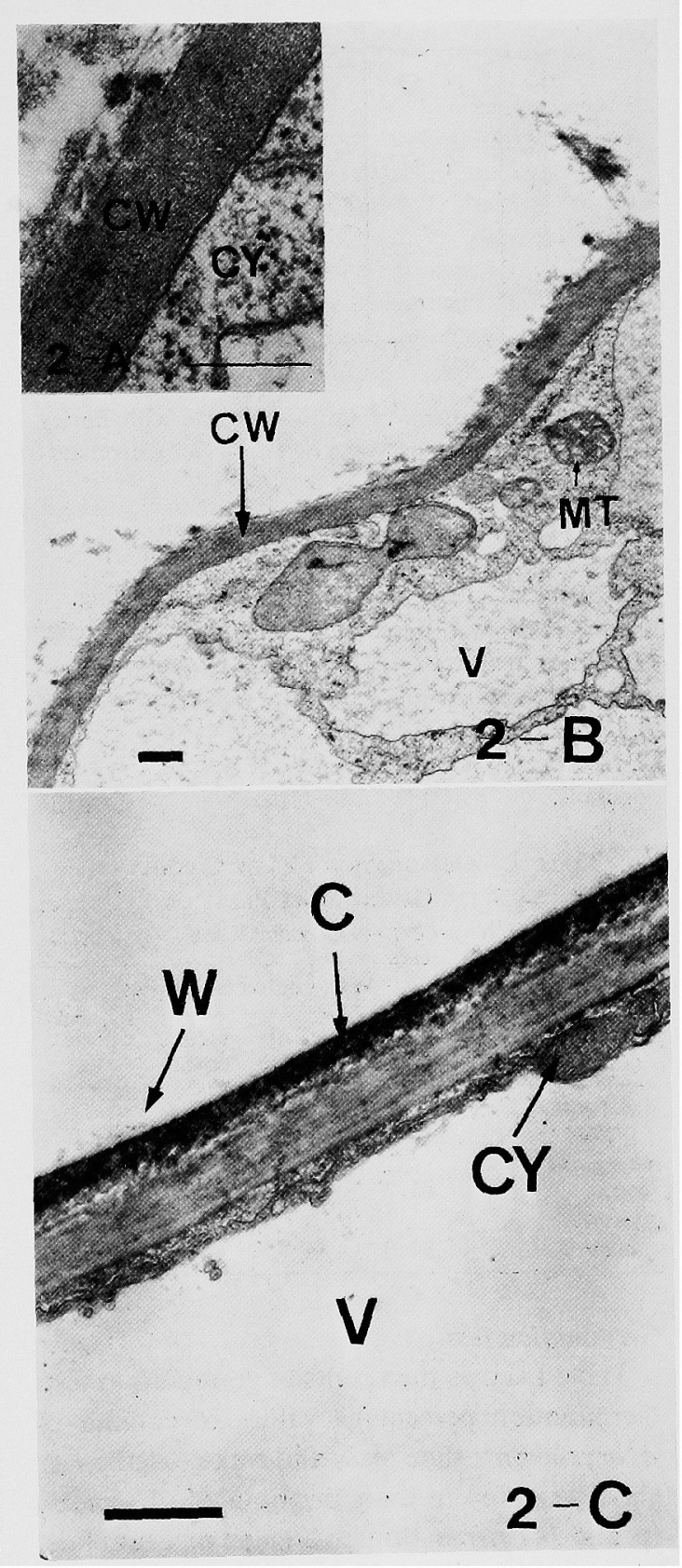

FIG. 2. Sectional Views of Callus and Plant Leaf. $A$ and $B$, Sectional views of rice callus tissues (Te-Tep). CW, Cell Wall; V, Vacuole; CY, Cytoplasm; MT, Mitochondria. C. Sectional view of barley leaves (Gose-shikoku). W, Wax; C, Cuticle.

The scale lines represent $1 \mu \mathrm{m}$.

lyophilized callus tissues, but no wax esters or ketones were detected. 


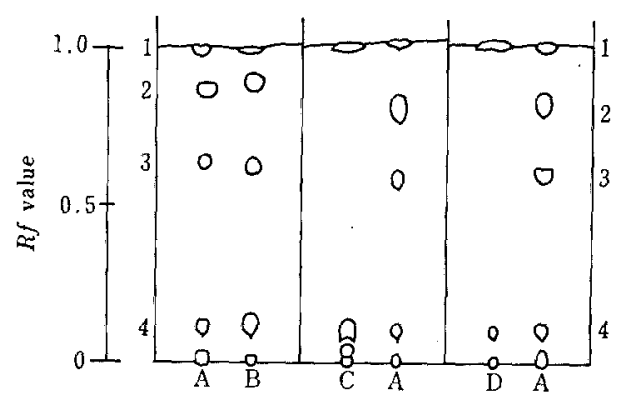

FIG. 3. Comparison of Callus Extracts with Barley and Rice Leaf Wax by Mean of Thin-layer Chromatography.

Thin-layer: Kieselgel $\mathrm{G}$, thickness $0.25 \mathrm{~mm}$.

Solvent system: benzene: $n$-hexane $(1: 1)$, Indicator: $50 \% \mathrm{H}_{2} \mathrm{SO}_{4}$ spray followed by charring.

A: Rice leaf wax, the amount of sample is $0.15 \mathrm{mg}$. B: Barley leaf wax, $0.11 \mathrm{mg}$. C: Lyophilized rice callus extract, $0.41 \mathrm{mg}$. D: Raw rice callus extract, $0.11 \mathrm{mg}$.

1, Hydrocarbons; 2, Wax esters; 3, Ketones; 4, Fatty alcohols.

Table I. Germination ( $\%$ ) OF Conidia on a Slide Glass, Agar Plate or Wax-Coated Cover Glass

\begin{tabular}{|c|c|c|c|c|}
\hline \multirow{2}{*}{ Microorganisms } & \multicolumn{4}{|c|}{ Wax-coated cover glass } \\
\hline & $\begin{array}{l}\text { Slide } \\
\text { glass }\end{array}$ & $\begin{array}{r}\text { Eicosil- } \\
\text { palmitate }\end{array}$ & $\begin{array}{l}\text { Octa- } \\
\text { cosan }\end{array}$ & $\begin{array}{c}1 \% \text { Agar } \\
\text { plate }\end{array}$ \\
\hline $\begin{array}{c}\text { Aspergillus } \\
\text { oryzae }\end{array}$ & 16.3 & 12.7 & 8.3 & 92.6 \\
\hline $\begin{array}{l}\text { Alternaria } \\
\text { sp., }\end{array}$ & 81.2 & 85.8 & 88.2 & 85.0 \\
\hline $\begin{array}{l}\text { Botrytis } \\
\quad \text { cinerea }\end{array}$ & 91.0 & 88.8 & 86.4 & not tested \\
\hline
\end{tabular}

\section{Germination test}

Table I shows the results of germination test. Germination percentage values of conidia of $A$. oryzae on a slide glass and wax-coated cover glass were lower than in those of Alternaria sp. and $B$. cinerea, though high on an agar plate. The results indicate that germination of spores of $A$. oryzae is less favored on hydrophobic membranes then that of spores of Alternaria sp. and $B$. cinerea.

\section{DISCUSSION}

Effects of environmental conditions on cuticle development ${ }^{6}$, have been discussed.
For instance, it is believed that high humidity prompts the development of a thin cuticle and dry atmosphere stimulates that of a thick one; the thickness of cuticle and waxiness of the leaf increase with a rise in light intensity. On the other hand, Priestley ${ }^{7}$ concluded that there was little or no relationship between the degree of xeromorphism and cuticle thickness. But cuticle development of oat and barley ${ }^{8}$ grown under controlled conditions was directly proportional to light and inversely proportional to relative humidity. Neither wax granules nor cuticle layer were observed on the outermost layer of callus tissues on the electron micrograph, and some parts of wax components were not detected in callus tissues by TLC. It seems that cuticle is either little or not developed under the cultural conditions of callus tissues such as high humidity and lack of light. Cuticle development may be also repressed by 2.4-D.

It has been generally considered that an important function of cuticle is the protection of plants against pathogens. The presence or absence of wax and cuticle seems to govern the wettability of leaves and germination of fungal spores which infect the host plant in an atmosphere of high relative humidity. In addition to its possible role as physical barrier, the cuticle may contain substances that inhibit the growth of fungi. J. T. Martin, ${ }^{9)}$ for example, suggested that an ether-soluble, acidic fraction of apple leaf wax was toxic to apple mildew fungus. S. $\mathrm{Akai}^{101}$ also reported that leaf wax of onions stimulated the formation of appressoria of Alternaria porri but spore germination was not affected. On the other hand, evidence that such barriers to the fungal penetration play a major factor in disease resistance is limited to a few special cases, and $H$. Wheeler ${ }^{11}$ considered that in many plants its contribution to protection would not be great.

Even if the disappearance of resistance ${ }^{11}$ in callus tissues cannot be attributed solely to cuticle development and thickness, we inferred that wettability of callus tissues and substances $^{12}$ leached from them by the lack of 
cuticle and wax facilitated spore germination and mycelial penetration. In fact, $A$. oryzae, a saprophytic and non-pathogenic fungus to rice, could also easily penetrate into callus tissues.

\section{REFERENCES}

1) N. Ogasawara, T. Uchiyama, T. Ohashi and H. Tanaka, Ann. Phytopath. Soc. Japan, in press.

2) O. Carter, Y. Yamada and E. Takahashi, Nature, 214, 1029 (1967).

3) T. Uchiyama, N. Ogasawara, M. Kobayashi and K. Amano, Nippon Nôgeikagaku Kaishi, 50, 351 (1976).

4) T. P. O'brien, Protoplasma, 63, 385 (1967).
5) P. E. Kolatukudy, Lipids, 5, 295 (1970).

6) J. T. Martin and B. E. Juniper, "The Cuticle of Plants," Edward Arnold Ltd., 1970, p. 72.

7) J. H. Priestley, Bot. Rev., 2, 293 (1943).

8) I. S. Yried, Y. K. Gaunt and D. Wynn Parry, Biochem. J., 109, 8 p. (1968).

9) J.T. Martin, R.F. Batt and R.T. Burchill, Nature, 180, 796 (1968).

10) S. Akai, M. Fukumoto, N. Ishida and H. Kunoh, "The Dynamic Role of Molecular Constituents in Plant Parasite Interaction," ed. by C. J. Mirocha, I. Uritani, St. Paul, Minn.: Am. Phytopathol. Soc., 1967, p. 1.

11) H. Wheeler, "Plant Pathogenesis," Spring-Verlag, 1975 , p. $6 \sim 13$.

12) H. B. Tukey, "Ecology of Leaf Surface Microorganisms," ed. by T. F. Preece and C. H. Dickinson, Academic Press, 1971, p. 67. 